\title{
THE ROLE OF AGRICULTURAL EXTENSION CENTERS IN RURAL DEVELOPMENT IN IRAQ
}

\author{
${ }^{1}$ Ahmed R. D. ALHealyi ${ }^{2}$ Dahham N. A. Aljarjary \\ ${ }^{1}$ Agricultural Extension Dept. - College of Agriculture and Forestry- University of \\ Mosul- Iraq \\ ${ }^{2}$ Agric. Extension Training Center in Nineveh \\ E.mail: ahmed0001988000@gmail.com
}

\begin{abstract}
The research aims to identify the role of agricultural extension centers in rural development in Iraq from the viewpoint of those working in, by identifying the degree to which agricultural extension centers play their role in rural development in the extension, economic and social fields. The degree to which these centers played their role in each of the aforementioned fields of rural development was determined and the items of these fields are arranged. The research community included (113) agricultural engineers and extensions working in the agricultural extension training centers in the country of (16) extension centers, except for the governorates of the Kurdistan region.

The results showed the agreement the views of most the respondents that the extension centers in Iraq play a major and effective role in rural development through carrying out tasks and works in all fields of studied rural development (in general). Likewise, most of the respondents views agreed that the economic field comes at the forefront of these fields and the social field came in the second rank, whereas the extension field came in the last rank. In the researcher's conclusions, he recommends the necessity of the continuity and support of the Ministry of Agriculture and those in charge of the extension apparatus in Iraq for extension centers due to the importance of its role in agricultural and rural development.
\end{abstract}

Keywords: agricultural extension centers, the rural development

Received: 6/7/2020 , Accepted: 19/11/2020

\section{INTRODUCTION}

The agricultural sector plays an important role in the economies of many developed and enhance countries of the world, and the countries of the world strive to develop the agricultural sector and develop it to meet the nutritional needs of the population and provide the necessary primary resources for many industries (Kashash, 2002). Agricultural and rural development is a strategy for developing the social and economic life of the rural population, through which job opportunities are increased income level is raised and housing, health and appropriate education are provided. It works to overcome poverty and achieve a decent life for rural residents (Al-Nur, 2012). The agricultural and rural development process has now become an important matter especially for developing countries. Achieving development goals requires attention to setting programs at all levels and in all fields, especially programs for educating the rural people and their families, modern agricultural methods that increase their productive efficiency and raise the standard of living of their societies. There is no dispute over the importance of agricultural extension in the rural development process,

The research is part of M.Sc. for $1^{\text {st }}$ researcher 
especially if there is a cooperation between agricultural extension and other Organizations Interested in creating development (Hassan et al, 2009). Agricultural extension work not only to increase in both plant and animal production or to seek an achieving technological progress in agricultural methods, but its message exceeds that scope to include creating rural social and economic development that lead to raising their living standards and advancing their local communities. (Kashash,2002). Agricultural extension programs are the cornerstone of rural community development, and extension work derive its important and vital role from the ability to provide new knowledge and ideas to create a change leads to improve rural people's life. (Qakley and Garforth, 1997). For the sake of extension work takes its role in agricultural and rural development, its necessary to have an appropriate methodology to choose good means which convey the extension massage. One of these methods and means is to publish and establish extension centers that are seen as one of the paths to achieve agricultural and even rural development from the perspective of their role in the direction of disseminating knowledge and modern technologies in a manner More effective (Nassif, 2006). It represents a base for extension work at the village level. And It undertakes planning, implementation and evaluation of extension programs in all fields of extension work. It also undertakes cooperation and coordination with research cadres, rural families, and civil and governmental organizations related to agricultural and rural development (Ghazi, 2019). He determine the tasks of the extension centers in all matters related to agriculture in terms of preparation, production, marketing, and attention to most aspects of family life, some issues of rural women and rural youth, local rural leadership, and rural resources (Shaker et.al, 2003). Several major roles have been identified for the extension centers, the planning role includes identifying the resources of the local community, setting its priorities, planning for agricultural development activities and programs, the supporting role contributes to solving agricultural rural problems, discovering local leaders, and the extension role is to transfer agricultural information and recommendations to farmers and raise their awareness of the developments and technologies Agricultural and their participation in extension programs, and the coordinating role in coordination with civil and governmental rural organizations within the scope of the work of the extension center (Al-Khafaji, 2013). The extension centers are considered a renewal of the extension work and the educational and extension services it provides aiming the positive change towards agricultural and rural progress for societies, families and rural individuals (Farid and Abdul-Hadi, 2003). To achieve this, the Ministry of Agriculture represented by the Agricultural Extension and Training Department in 2005 AD Establishing a scientific program to establish an extension network through setting up extension centers in Governorates centers and extension farms in a number of agricultural divisions in the governorates, which are among the projects and programs related to rural development goals (Nassif, 2006). Thus, (16) extension centers and (57) extension farms belonging to these centers were published and established, and these extension centers and farms were equipped with the needs and requirements that would enable them to perform their work and achieve the goals set for them (Al-Khafaji, 2013). According to the above, it was found that the Agricultural Extension in Iraq represented by the Agricultural Extension and Training office And 
with its various departments, including agricultural extension training centers, it makes great efforts to bring about agricultural and rural development, despite the important role Which agricultural extension training centers undertake in the various rural development fields, but the rates of development in the Iraqi rural community are not tangible and below the level of ambition, which indicates a weakness or deficiency in the performance of extension services for some extension centers or their failure to perform the tasks assigned to them as required, or There are problems and obstacles facing the work of these extension centers in achieving rural development, and given the limited research and studies that dealt with the role of extension centers in achieving rural development, the matter requires conducting some research and studies on the reality of the status of these centers, leading to results that provide an opportunity for those in charge of managing the extension system in Iraq To make benefit from it and improve the effectiveness of extension centers' performance and enable them to provide extension services and achieve the goals of agricultural extension and programs, in order to achieve rural development. Therefore, the problem of this research is limited to answering the following questions:

1 - What is the degree to which agricultural extension centers in Iraq play a role in rural development in general?

2- What is the degree to which agricultural extension centers in Iraq play their role in every field of rural development (extension, economic and social)?

\section{OBJECTIVES OF STUDY}

1- Identifying the role of agricultural extension centers in rural development in Iraq in the fields studied in general (extension, economic, and social) from the viewpoint those working in.

2- Identifying the degree of extension centers in their role in rural development for every field of rural development (extension, economic, and social).

3- Arranging the items for each of the rural development fields (extension, economic and social).

\section{MATERIALS AND METHODS}

The study field included all the provinces of Iraq except of the provinces of the Kurdistan region, where the targeted region has huge potentials of vast agricultural lands, not many water sources and a suitable climate for agricultural diversity, and if it invested according to scientific foundations, it is possible to provide the largest part of the needs of the population in the region and Iraq as well. There are (16) extension centers in the study area, in addition to (57) extension farms. The research community is represented by all agricultural employees, regardless of their specialties, and those working in extension centers for agricultural training in the governorates of Iraq, with the exception of the governorates of the Kurdistan Region, which are (216) agricultural engineers and guides, according to statistics of the Agricultural Extension and Training Department/ Planning and Follow-up Department, accordingly, As for the type of sample, it was comprehensive, (220) forms were distributed A questionnaire on those covered by the research in the extension centers, and data was collected from (113) agricultural engineers and extension workers after excluding (30) agricultural engineers and extension workers who included to measure the reliability of the questionnaire form and neglect some of the forms because of the incompleteness of 
their information and also it was not possible to contact some members of the research community for the security conditions in some governorates in the country During the period of research data collection which led to a variation in the percentage of the research sample. Table (1) shows the distribution of respondents to the extension centers in the governorates included in the study.

Table (1): shows the distribution of the respondents according to the extension centers in the governorates

\begin{tabular}{|c|c|c|c|}
\hline No & The name of the counseling center & Number & ercentage \\
\hline 1 & Extension Center in Baghdad & 14 & 12.39 \\
\hline 2 & Extension Center in Wasit & 12 & 10.62 \\
\hline 3 & Extension Center in Najaf & 11 & 9.74 \\
\hline 4 & Extension Center in Nineveh & 11 & 9.74 \\
\hline 5 & Extension Center in Basra & 10 & 8.85 \\
\hline 6 & Extension Center in Kirkuk & 9 & 7.96 \\
\hline 7 & Extension Center in Dhi Qar & 7 & 6.29 \\
\hline 8 & Extension Center in Diyala & 6 & 5.31 \\
\hline 9 & Extension Center in Maysan & 6 & 5.31 \\
\hline 10 & Extension center in Salah al-Din & 5 & 4.42 \\
\hline 11 & Extension Center in Holy Karbala & 5 & 4.42 \\
\hline 12 & Extension Center in Babylon & 5 & 4.42 \\
\hline 13 & Extension Center in Anbar & 4 & 3.54 \\
\hline 14 & Extension center in Tal Afar & 4 & 3.54 \\
\hline 15 & Extension Center in Qadisiyah & 2 & 1.77 \\
\hline 16 & Extension Center in Muthanna & 2 & 1.77 \\
\hline & Total & 113 & $\% 100$ \\
\hline
\end{tabular}

RESUITS AND DISCUSSION

1- Identifying the role of agricultural extension centers in rural development in Iraq from the viewpoint of workers in them in general.

Determine the degree to which the extension centers play their roles in rural development in all fields studied in general (extension, economic, and social) from the viewpoint of those working in. The degree to which the extension centers play their roles in rural development in general is classified into three categories depending on the theoretical extent, as the researcher gets the lowest numerical value (41) degree, 
and the highest numerical value (123) degree with an average arithmetic score (94.70) and a standard deviation (18.911), and the first category included the low role (41-67) degrees and the second category (68-94) degrees, which is the moderate stage. As for the third category, it was confined between (more than 95) degrees, which is the major high, as shown in Table (2).

Table (2): The degree to which the extension centers managed it in rural development in general from the viewpoint of its employees

\begin{tabular}{|c|c|c|c|}
\hline Categories & Number & Percentage & $\begin{array}{c}\text { Arithmetic } \\
\text { mean }\end{array}$ \\
\hline Low Role (41-67) & 10 & 8.8 & 58.33 \\
\hline Moderate Role (68-94) & 41 & 36.3 & 81.73 \\
\hline High Role (more than 95) & 62 & 54.9 & 109.14 \\
\hline Total & 113 & $\% 100$ & \\
\hline
\end{tabular}

And that $(8.8 \%)$ of the respondents believe that the extension centers play their role in rural development in the fields studied in general in a Few degree, and that $(36.3 \%)$ of the respondents believe that the extension centers play their role in rural development in general an average degree, while he sees $(54.9 \%)$ Of the respondents said that the extension centers play a major role in rural development. It is clear from the above that the views of most of the respondents agree that the extension centers play an effective role in rural development through carrying out tasks and works in all fields studied, and the reason for this may be due to the efforts made by workers in these centers and the ongoing support provided by officials in charge of the agency extension in Iraq, which leads to these centers playing an important role in rural development in Iraq, and it is clear from these results that there is agreement with the study (Habib and others, 2010), (Naji and Khafaji, 2012) and (Ghazi, 2019).

2- Determine the degree of agricultural extension training centers in each of the abovementioned fields of rural development.

2-1-The extension field: The degree of extension centers' role in rural development in this field has been classified into three categories where the theoretical range ranged between (16-48), and Table (3) shows that (11.504\%) of the respondents with an arithmetic mean of (22.641) They see that the extension centers play their role in rural development in the extension field with a low degree, while (42.478\%) of the respondents see an arithmetic mean $(32,583)$ that the extension centers play their role in the rural development in the extension field with an moderate degree, while $(46.018 \%)$ of The respondents, with an arithmetic mean of $(42,942)$ see that the centers play a high role in rural development in the extension field.

2-2-The economic field: The degree of the extension centers' role in rural development in the economic field was classified into three categories depending on the theoretical scope, where the theoretical range ranged between (13-39) degrees and table (4) shows that $(7.965 \%)$ of the respondents with an arithmetic average (18.111) believe that the extension centers play their role in rural development in the economic field with a low 
degree, while $(39.823 \%)$ of the respondents an Arithmetic mean of $(26,677)$ They see that the extension centers play their role in the development in the economic field with a moderate degree, while the rest of the respondents $(52.212 \%)$ With an arithmetic mean of $(35,898)$ The see the extension centers play their role in rural development in the economic field to a high extent.

Table (3): The degree to which extension centers play their role in rural development in the extension field from the viewpoint of those working in them

\begin{tabular}{|c|c|c|c|}
\hline Categories & Number & Percentage & $\begin{array}{c}\text { Arithmetic } \\
\text { mean }\end{array}$ \\
\hline Low Role (16-26) & 13 & 11.504 & 22.641 \\
\hline Moderate Role (27-37) & 48 & 42.478 & 32.583 \\
\hline High Role(38 -48) & 52 & 46.018 & 42.942 \\
\hline Total & 113 & $\% 100$ & \\
\hline
\end{tabular}

Table (4): The degree to which the extension centers play their role in rural development in the economic field from the viewpoint of those working in

\begin{tabular}{|c|c|c|c|}
\hline Categories & Number & Percentage & $\begin{array}{c}\text { Arithmetic } \\
\text { mean }\end{array}$ \\
\hline Low Role(13-21) & 9 & 7.965 & 18.111 \\
\hline Moderate Role(22-30) & 45 & 39.823 & 26.677 \\
\hline High Role(31 -39) & 59 & 52.212 & 35.898 \\
\hline Total & 113 & $\% 100$ & \\
\hline
\end{tabular}

2-3-The social field: The degree of extension centers' role in rural development in this field has been classified into three categories where the theoretical range ranged between (12-36) degrees, and Table (5) shows that (13.274\%) of the respondents with an arithmetic mean of $(16,666))$ They see that the extension centers play their role in rural development in the social field to a low degree, while (28.319\%) of the respondents with an arithmetic mean of (23.375) They see that the extension centers play a moderate role in rural development in the social field, while $(58.407 \%)$ of The respondents, with an arithmetic mean of $(32,515)$, the extension centers play a high role in rural development according to the social field.

Table (5): The degree to which the extension centers play their role in rural development in the social field from the viewpoint of those working in them

\begin{tabular}{|c|c|c|c|}
\hline Categories & Number & Percentage & $\begin{array}{c}\text { Arithmetic } \\
\text { mean }\end{array}$ \\
\hline Low Role(12-19) & 15 & 13.274 & 16.666 \\
\hline Moderate Role(20-27) & 32 & 28.319 & 23.375 \\
\hline High Role(28 \& more) & 66 & 58.407 & 32.515 \\
\hline Total & 113 & $\% 100$ & \\
\hline
\end{tabular}

Table (6) shows that the economic field ranks first among the fields of rural development studied with an arithmetic mean of (2.360) degrees and a degree of 
Mesopotamia J. of Agric.

Vol. (48) No. (4) 2020
ISSN: 2224 - 9796 (Online)

ISSN: 1815 - 316 X (Print)

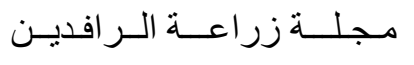

المجلا (48) العدد (4) 2020

verification (78.667\%). The social field came in second rank with an arithmetic mean of (2.320) degrees and a degree of verification (77.333\%), and the extension field came at the last rank with an arithmetic mean of (2.261) degrees and a degree of achievement (75.367\%). Accordingly, it is clear from the above that the views of the respondents agree that the agricultural extension training centers in Iraq play their main roles in the studied rural development fields even if the degree of their fulfillment of these roles varies, which requires exerting more effort, hard work and continuous future support by those in charge of Agricultural extension in Iraq for these centers to play an effective role in rural development through social renaissance make through economic renaissance by exploiting all the natural or human resources and capabilities and education and awareness of farmers and their rural families and improving their skills and changing their attitudes so that they can fully benefit from progress Scientific and technological in agriculture, which leads to raising their living standards and advancing their local societies.

Table (6): Arranging the studied rural development fields according to the degree of their achievement

\begin{tabular}{|c|c|c|c|}
\hline $\begin{array}{c}\text { Fields of rural } \\
\text { development }\end{array}$ & Rank & $\begin{array}{c}\text { Arithmetic } \\
\text { mean }\end{array}$ & $\begin{array}{c}\text { Centenary } \\
\text { weight }\end{array}$ \\
\hline The economic field & 1 & 2.360 & 78.667 \\
\hline The social field & 2 & 2.320 & 77.333 \\
\hline The extension field & 3 & 2.261 & 75.367 \\
\hline
\end{tabular}

Maximum degree $=3$

3- Arrange the items for each of the studied rural development fields according to their severity and degree of achievement

3-1- Table (7) shows the arrangement of the items in the economic field that the item that came first is (the diffusion of modern irrigation techniques as an economic necessity to rationalize the use of irrigation water) where its arithmetic mean (2.637) and the degree of its achievement $(87.900 \%)$, and this indicates high interest by Agricultural Extension Department for this aspect, as water is the backbone of life and an important component in all agricultural processes and as a result of the shortage of water sources, especially in times of drought, which requires more extension efforts, planning and implementing extension programs, and selecting the most appropriate extension methods in educating and guiding farmers and their rural families in implementing Water conservation practices and modern irrigation methods. As for the item that came in the last rank, it is (the definition of farmers, companies and agents of agricultural production requirements in the fields of the extension center), and its arithmetic mean was (2.185) and the degree of investigation (72.833\%). Extension services for farmers. 
Mesopotamia J. of Agric.

Vol. (48) No. (4) 2020
ISSN: 2224 - 9796 (Online)

ISSN: 1815 - 316 X (Print)

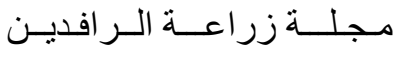

المجلد (48) العدد (4) 2020

Table (7): Arrangement the items of the economic field in descending order according to their degree of achievement and intensity

\begin{tabular}{|c|c|c|c|}
\hline Items & Rank & $\begin{array}{l}\text { Arith-metic } \\
\text { mean }\end{array}$ & $\begin{array}{l}\text { Centenary } \\
\text { weight }\end{array}$ \\
\hline $\begin{array}{l}\text { the diffusion of modern irrigation techniques as an } \\
\text { economic necessity to rationalize the use of irrigation } \\
\text { water }\end{array}$ & 1 & 2.637 & 87.900 \\
\hline $\begin{array}{l}\text { Introducing farmers to the recommended agricultural } \\
\text { production requirements (improved seeds, fertilizers, } \\
\text { pesticides) }\end{array}$ & 2 & 2.548 & 84.933 \\
\hline $\begin{array}{l}\text { Helping farmers to identify the problems they face in } \\
\text { agriculture and production and find appropriate solutions } \\
\text { to them }\end{array}$ & 3 & 2.522 & 84.067 \\
\hline $\begin{array}{l}\text { Educate and guide farmers and urge them to know the } \\
\text { laws and regulations related to the conservation of } \\
\text { livestock }\end{array}$ & 4 & 2.469 & 82.300 \\
\hline $\begin{array}{l}\text { Awareness of rural families to benefit from agricultural } \\
\text { waste in setting up rural industries to develop economic } \\
\text { resources }\end{array}$ & 5.5 & 2.353 & 78.433 \\
\hline $\begin{array}{c}\text { Educating and guiding farmers in establishing } \\
\text { specialized societies, such as water users societies }\end{array}$ & 5.5 & 2.353 & 78.433 \\
\hline $\begin{array}{l}\text { Enabling rural youth to establish small productive } \\
\text { enterprises as a source of income }\end{array}$ & 7 & 2.326 & 77.567 \\
\hline $\begin{array}{l}\text { Raise awareness of farmers and their rural families about } \\
\text { environmental resources and how to use, maintain and } \\
\text { preserve them }\end{array}$ & 8 & 2.283 & 76.100 \\
\hline $\begin{array}{l}\text { Empowering rural women to establish small productive } \\
\text { enterprises as a source of income }\end{array}$ & 9 & 2.274 & 75.800 \\
\hline $\begin{array}{l}\text { Contribute to improving the standard of living of } \\
\text { farmers and improving their economic level by } \\
\text { increasing production and thus increasing income }\end{array}$ & 10.5 & 2.265 & 75.500 \\
\hline $\begin{array}{l}\text { Assist farmers in marketing their agricultural products } \\
\text { using the correct marketing methods }\end{array}$ & 10.5 & 2.265 & 75.500 \\
\hline $\begin{array}{c}\text { Knowing the local community's resources to determine } \\
\text { its priorities in planning agricultural and animal } \\
\text { extension activities }\end{array}$ & 12 & 2.203 & 73.433 \\
\hline $\begin{array}{l}\text { the definition of farmers, companies and agents of } \\
\text { agricultural production requirements in the fields of the } \\
\text { extension center }\end{array}$ & 13 & 2.185 & 72.833 \\
\hline
\end{tabular}

3-2- Table (8) also shows the arrangement of the items of the social field, and that the item that ranked first in the social field from the viewpoint of the respondents is (working to increase the confidence of farmers in the extension center in providing solutions to their problems) with an arithmetic mean of (2.442) and the degree of achievement $(81.400 \%)$ Where the process of gaining the confidence of farmers is 
Mesopotamia J. of Agric.

Vol. (48) No. (4) 2020
ISSN: 2224 - 9796 (Online)

ISSN: 1815 - 316 X (Print)

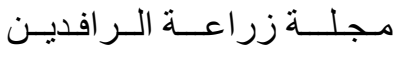

المجلد (48) العدد (4) 2020

considered one of the main pillars of extension work, and increasing the confidence of farmers in the extension centers works to form distinguished relations with farmers based on friendliness, respect, and effective participation in the fields of agricultural and even rural development in them . As for the item that came last, it is (cooperation and coordination with civil and governmental organizations concerned with the development of rural fields) with an arithmetic mean of $(2,176)$ and the degree of investigation $(72,533 \%)$. A series of references to obtain official approvals in dealing with them, as well as the lack of unified development plans, since each organization has its goals and objectives

Countries (8): Arrange the items of the social field according to the degree of its achievement and its intensity.

\begin{tabular}{|c|c|c|c|}
\hline Items & Rank & $\begin{array}{l}\text { Arith-metic } \\
\text { mean }\end{array}$ & $\begin{array}{c}\text { Cente } \\
\text { nary } \\
\text { weight }\end{array}$ \\
\hline $\begin{array}{l}\text { Work to increase the confidence of farmers in the } \\
\text { extension center in providing solutions to their problems }\end{array}$ & 1 & 2.442 & 81.400 \\
\hline $\begin{array}{l}\text { Transferring the problems and suffering of the rural } \\
\text { population to the relevant authorities }\end{array}$ & 2 & 2.415 & 80.500 \\
\hline $\begin{array}{c}\text { Educating and educating farmers to adopt modern } \\
\text { agricultural ideas }\end{array}$ & 3 & 2.407 & 80.233 \\
\hline $\begin{array}{l}\text { Raising awareness and guiding farmers and their rural } \\
\text { families about the environmental culture according to } \\
\text { extension programs designed for this purpose }\end{array}$ & 4 & 2.383 & 79.433 \\
\hline $\begin{array}{l}\text { Work on the farmers' contribution in planning extension } \\
\text { programs within the geographical field of the extension } \\
\text { work }\end{array}$ & 5 & 2.327 & 77.567 \\
\hline $\begin{array}{l}\text { Developing the cooperative spirit of farmers by joining } \\
\text { the agricultural cooperative societies in a way that serves } \\
\text { the development of agricultural operations }\end{array}$ & 6.5 & 2.309 & 76.967 \\
\hline $\begin{array}{c}\text { Developing farmers' participation in using the principle of } \\
\text { rationality in taking the appropriate decision to solve its } \\
\text { agricultural problems }\end{array}$ & 6.5 & 2.309 & 76.967 \\
\hline $\begin{array}{l}\text { Work to integrate rural youth into rural development } \\
\text { processes }\end{array}$ & 8 & 2.300 & 76.667 \\
\hline $\begin{array}{l}\text { Providing new knowledge and ideas, not bringing about } \\
\text { social change that improves the lives of rural people }\end{array}$ & 9 & 2.292 & 76.400 \\
\hline $\begin{array}{c}\begin{array}{c}\text { Spreading knowledge and deepening awareness of } \\
\text { development issues }\end{array} \\
\text {. }\end{array}$ & 10 & 2.274 & 75.800 \\
\hline Discovering and developing rural leaders & 11 & 2.203 & 73.433 \\
\hline $\begin{array}{l}\text { Cooperation and coordination with civil and } \\
\text { governmental organizations concerned with the } \\
\text { development of rural fields }\end{array}$ & 12 & 2.176 & 72.533 \\
\hline
\end{tabular}

3-3- Table (9) shows that the item that came first in the extension field is (holding extension seminars in various agricultural issues, both plant and animal) with an 
Mesopotamia J. of Agric.

Vol. (48) No. (4) 2020
ISSN: 2224 - 9796 (Online)

ISSN: 1815 - 316 X (Print)

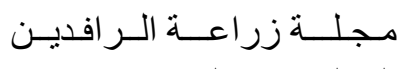

المجلد (48) العدد (4) 2020

arithmetic mean of (2.619) and a degree of achievement (87.300\%), and this indicates the great interest of extension centers in executive matters. By holding guiding seminars and providing the requirements for their convening, in addition to the fact that the workers in these centers have the competence and experience in managing and organizing these seminars, and the reason for that may be due to the effectiveness of guiding seminars in communicating guiding recommendations in various agricultural issues to farmers. As for the item that came in the last rank, it is (Participate in preparing agricultural and rural research and extension studies) with an arithmetic mean of (1.920) and the degree of its achievement (64.000\%). Research and extension studies within the programs of Agricultural Extension and Training .

Table (9): The arrangement of the items of the extension field according to the degree of its achievement and its severity

\begin{tabular}{|c|c|c|c|}
\hline Items & Rank & $\begin{array}{l}\text { Arith-metic } \\
\text { mean }\end{array}$ & $\begin{array}{l}\text { Centenary } \\
\text { weight }\end{array}$ \\
\hline $\begin{array}{l}\text { holding extension seminars in various agricultural } \\
\text { issues, both plant and animal }\end{array}$ & 1 & 2.619 & 87.300 \\
\hline $\begin{array}{l}\text { Developing the performance efficiency of rural youth } \\
\text { and youth in agricultural issues, both plant and animal }\end{array}$ & 2 & 2.513 & 83.767 \\
\hline $\begin{array}{l}\text { Establish demonstration fields in the fields of farmers } \\
\text { and extension farms as a means of agricultural } \\
\text { guidance }\end{array}$ & 3 & 2.495 & 83.167 \\
\hline $\begin{array}{c}\text { Developing the performance efficiency of employees } \\
\text { working in the agricultural sector through training } \\
\text { courses }\end{array}$ & 4 & 2.486 & 82.867 \\
\hline $\begin{array}{l}\text { Establishing field days in the fields of farmers and } \\
\text { extension farms for agricultural crops proven to be } \\
\text { successful }\end{array}$ & 5 & 2.433 & 81.100 \\
\hline $\begin{array}{c}\text { Developing the performance efficiency of rural } \\
\text { women and girls through training programs in various } \\
\text { fields }\end{array}$ & 6 & 2.389 & 79.633 \\
\hline $\begin{array}{l}\text { Distributing informative publications of all kinds in a } \\
\text { way that suits the educational capabilities of workers } \\
\text { in the agricultural sector in their different classes }\end{array}$ & 7 & 2.327 & 77.567 \\
\hline $\begin{array}{c}\text { Establishing workshops in all different agricultural } \\
\text { activities }\end{array}$ & 8.5 & 2.318 & 77.267 \\
\hline $\begin{array}{l}\text { Training farmers in the latest results of agricultural } \\
\text { research that are applicable and recommendations }\end{array}$ & 8.5 & 2.318 & 77.267 \\
\hline Participation in holding agricultural exhibitions & 10 & 2.159 & 71.967 \\
\hline $\begin{array}{l}\text { Providing training opportunities for some different } \\
\text { segments of society in protecting the environment } \\
\text { from pollution and working to develop them }\end{array}$ & 11 & 2.115 & 70.500 \\
\hline $\begin{array}{l}\text { Adopting a field school method as a means of } \\
\text { participatory extension among farmers }\end{array}$ & 12 & 2.061 & 68.700 \\
\hline
\end{tabular}




\begin{tabular}{|c|c|c|c|}
\hline $\begin{array}{c}\text { Contributing to the implementation of literacy } \\
\text { programs in the countryside in coordination and } \\
\text { cooperation with the general directorates of education }\end{array}$ & 13 & 2.053 & 68.433 \\
\hline $\begin{array}{c}\text { Providing summer training opportunities for students } \\
\text { of agricultural universities and colleges }\end{array}$ & 14 & 1.991 & 66.367 \\
\hline Participate in setting up agricultural festivals & 15 & 1.982 & 66.067 \\
\hline $\begin{array}{c}\text { Participate in preparing agricultural and rural research } \\
\text { and extension studies }\end{array}$ & 16 & 1.920 & 64.000 \\
\hline
\end{tabular}

\section{CONCLUSIONS}

1- The agricultural extension centers in Iraq play a large and effective role in the areas of rural development in general, according to the results of the study, where most of the researchers agreed that the extension centers play their main roles in rural development, even if the degree of their performance varies.

2- The economic field comes at the forefront of the studied rural development areas, and then the social field and finally the extension field. We conclude from this that most of the activities of the extension centers focus on the tangible material aspect to raise the standard of living of the rural areas population.

3- Through arranging the paragraphs of tasks and duties related to the role of extension centers in rural development for the studied areas that were shown by the results of the study show that the spread of modern irrigation techniques as an economic necessity comes first in the economic field, and work to increase the confidence of farmers in extension centers in providing solutions to their problems in the social field, And holding guiding seminars on various agricultural issues, both plant and animal, for the guiding field. We conclude from this the importance of these paragraphs in the areas of agricultural, and even rural, development.

Recommendations

1- The necessity of the continued support of the Iraqi Ministry of Agriculture for extension centers, due to the importance of its role in agricultural and rural development, and ensuring that the main role of extension centers is to encourage the target groups of farmers, women, rural girls, young people and rural youth to learn and attend extension activities and to take guidance recommendations that serve the areas of rural development.

2- The necessity of the Agricultural Extension and Training Office to pay attention to providing the necessary financial allocations for the extension centers to play their roles in agricultural and rural development, taking into account a balance in support for extension activities implemented by these centers.

3- With the aim of gaining the trust of the targeted from the services of extension centers and ensuring a distinct role for the extension centers, announcing their extension activities before their implementation, and notifying the agricultural directorates and local federations of the agricultural societies to urge the targeted groups to attend these activities. 


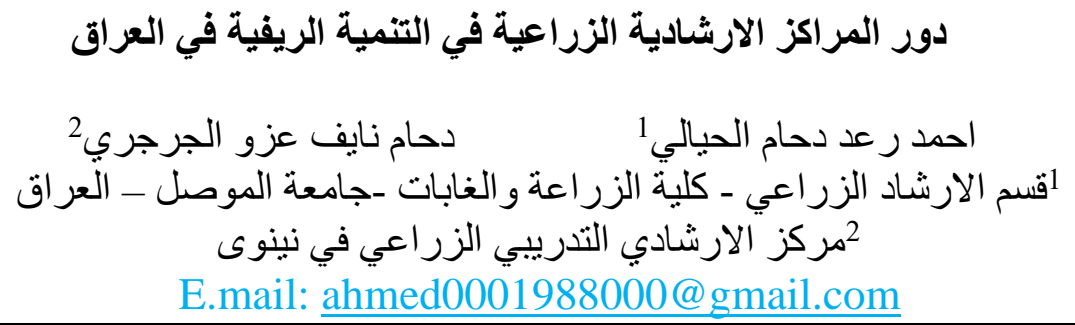

\begin{abstract}
الخلاصة
يستهدف هذا البحث بشكل رئيسي التعرف على دور المراكز الارشادية الزراعية في التتمية الريفية في العراق من وجهة نظر العاملين فيها، ذلك من خلال تحديد درجة قيام المراكز الارشادية الزراعية بدورها في التنمية الريفية في المجالات الارشادية والاقتصادية والاجتماعية بشكل عام. وتحديد درجة قيام هذه المراكز بدورها في كل مجال من مجالات التتمية الريفية المذكورة انفا وترتيب فقرات هذه المجالات. حيث شملت مجتمع البحث (113) مهندسا ومرشدا زراعيا من العاملين في المراكز الارشادية التدريبية الزراعية في القطر البالغ (16) مركزا ارشاديا باستثناء محافظات اقليم كردستان. اظهرت النتائج اتفاق وجهات نظر اغلب المبحوثين على ان المراكز الارشادية في العراق تقوم بدور كبير وفعال في التتمية الريفية من خلال قيامها بالمهام والاعمال في جميع مجالات التتمية الريفية المدروسة (الارشادية، الاقتصادية، الاجتماعية) بشكل عام. كذلك اتفاق وجهات نظر اغلب المبحوثين على ان المراكز الارشادية في العراق تقوم بأدوارها الرئيسية في مجالات التتمية الريفية المدروسة حيث يأتي في مقدمة هذه المجالات المجال الاقتصادي ثم جاء المجال الاجتماعي بالمرتبة الثانية اما المجال الارشادي فقد جاء في المرتبة الاخيرة ـ وفي ضوء ما توصل اليه الباحث من استتناجات يوصي على ضرورة استمرار ودعم وزارة الزراعة والقائمين على لى لهي الجهاز الارشادي في العراق للمراكز الارشادية وذلك لأهمية دورها في التتمية الزراعية والريفية.

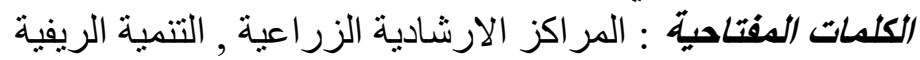

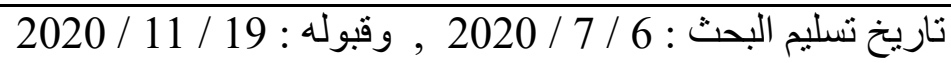

\title{
REFERENCES
}

Al-Khafaji, S. K.(2013) Effectiveness of extension activities of extension centers in Wasit Governorate from the viewpoint of farmers and their relationship to some factors, Technical Education Authority, Dhi Qar University Journal for Agricultural Research, 2, (1) 125-141.

Al-Nour, M. A. M. (2012) Rural Development, Security and Life Journal, No. (365),53-70 .

Farid, M. A. and A-H. M. El-Gawad (2003) Quality of agricultural extension services for agricultural extension centers in Egypt from the point of view of agricultural extension centers officials, Egyptian Journal of Agricultural Sciences, 81, (3) 1402.

Ghazy, R. W. A- S. (2019). The role of agricultural extension centers in sensitizing rural women in the field of nutritional education in Dakahlia Governorate, Agricultural Journal of Social and Economic Sciences 10,( 6) 315-320.

Hassan, A. H. , S. M. Morsi and M. M. Barakat (2009) Agricultural Extension, Faculty of Agriculture, Ain Shams University, Egypt.20-54 
Kashash, B. H.(2002), The Reality of agricultural extension in Al-qadisiyah governorate, Al-Qadisiyah Journal for Educational Sciences, No. (2)217-218 .

Nassif, Asem Ismail (2006). The extension network. The extension centers and extension farms are a step on the road to achieving rural development. Iraqi Agriculture Journal, first issue.NO (1) 14-26

Qakley , p. and C. Garforth. (1997) Guide to Extension Training, Agriculture of Extension and Rural Development center, school of Education, university of Reading, UK, Available AT ; www.fao-org docrep / too60e, 3-12

Shaker, M. , M. Farid and A- F. Said (2003) Agricultural Extension Centers in Egypt, Present Status and Future Needs at the Sixth Conference on Agricultural Extension and Rural Development, National Dialogue Program on Extension Work Issues, Center for Extension Services and Agricultural Consultations, Faculty of Agriculture, Mansoura University, 121-134. 